\title{
„Zapomniana demokracja” \\ O demokracji deliberacyjnej \\ w Pierwszej Rzeczypospolitej
}

\section{Uwagi wstępne}

Pojęcie demokracji ma bardzo wiele znaczeń; w dziejach znano różne jej odmiany. Uchodzi współcześnie za najlepszy ustrój, choć ma również bardzo dużo przeciwników. Wiążą się z nią piękne idee wolności i równości ludzi nie tylko w życiu prywatnym, ale także publicznym. Tradycje demokratyczne uważa się za istotne dla rozwoju demokracji w poszczególnych krajach. Nie zawsze jednak istnienie takich korzeni ocenia się pozytywnie; wcześniejsze doświadczenia oznaczają, że demokracja w tym państwie upadła, a zatem nie była ustrojem odpowiednim. To może sprzyjać kształtowaniu się postaw niechętnych przejściu na drogę przemian demokratycznych. $Z$ drugiej strony, tradycje demokratyczne wytyczają kierunek, ku któremu państwo powinno zmierzać; demokracja społeczeństwu w tym kraju nie jest całkowicie nieznana.

Współczesna nauka rzadko odwołuje się do staropolskich tradycji demokratycznych, a jeśli to czyni, to nadal w dużej mierze w znaczeniu pejoratywnym. W społeczeństwie tkwi głęboko przekonanie, że w czasach staropolskich panowała anarchia i bezprawie, a tego okresu historycznego powinniśmy się wstydzić. 


\section{Pojęcie demokracji w ujęciu współczesnym}

Współcześnie pojmuje się demokrację w rozmaitych ujęciach. $\mathrm{W}$ ujęciu konstytucyjnym to deklaracja zawarta w przepisach ustrojowych; zauważa się wszakże duże rozbieżności między normatywnymi deklaracjami a praktyką życia publicznego. Rzeczowe rozumienie demokracji oznacza pewien system, który umacnia dobrobyt ludzi, wolność jednostki, bezpieczeństwo, równość społeczną oraz pokojowe rozwiązywanie konfliktów. W ujęciu procesualnym demokracja skupia się na procedurach prawnych, regulujących działania instytucji oraz udział obywateli. Gdy zaś mamy na myśli zespół procesów, które muszą się toczyć nieprzerwanie, w tym włączające obywatelstwo, wolne, uczciwe i częste wybory, autonomia stowarzyszeń, a nadto stosowanie w możliwie najszerszym zakresie wolności słowa oraz pozyskiwanie alternatywnych źródeł informacji, to wówczas demokrację rozumiemy w kontekście procesualnym ${ }^{1}$.

W celu przybliżenia tego pojęcia używa się różnych określających ją przymiotników. Demokracja republikańska oznacza nastawienie na procedury wyborcze jako najważniejszy aspekt demokracji. Z kolei partycypacja społeczna ma podkreślać udział obywateli w urządzeniach demokratycznych; w tym kontekście mówimy o demokracji partycypacyjnej. We współczesnym świecie aspekt ten odgrywa szczególną rolę. W literaturze podkreśla się, że partycypacja obywateli jest podstawowym warunkiem istnienia ustroju demokratycznego, a jej zakres świadczy o sile demokracji w danym kraju ${ }^{2}$.

1 Ch. Tilly, Demokracja, przekł. M. Szczubiałka, Warszawa 2008, s. 18-21.

2 Por. D. Długosz, J. Wygnański, Obywatele współdecydują. Przewodnik po partycypacji społecznej, Warszawa 2005. 


\section{Tradycje demokracji partycypacyjnej w świetle literatury przedmiotu}

Powszechność partycypacji ma istotne znaczenie dla wskazania genezy demokracji. Dlatego część badaczy tego zagadnienia sytuuje początki demokracji w XX wieku, gdy pojawił się szeroki dostęp do instytucji demokratycznych. W szczególności podnosi się, że czynne i bierne prawa wyborcze, ograniczone jedynie cenzusem wieku lub wyłączone przez prawomocne pozbawienie praw obywatelskich, stało się powszechnie dostępne dopiero po 1918 roku. $Z$ tego powodu część literatury przedmiotu odrzuca istnienie demokracji we wcześniejszych okresach historycznych, także w starożytnej Grecji, wskazując na faktyczne niewolnictwo obywateli w polis greckich. Nie istniała w tych czasach wolność jednostki, której wszelkie działania musiały być podporządkowane dobru państwa.

Jednak $z$ drugiej strony zauważa się pierwiastki demokracji zarówno bezpośredniej, jak i pośredniej już w starożytności. Najważniejsze decyzje w sprawach polis, a mianowicie uchwalanie prawa, powoływanie i odwoływanie urzędników, sądownictwo w sprawach przestępstw przeciwko państwu, podejmowano na zgromadzeniu ludowym (eklezji). W celu zachęty do udziału w nim biedniejszych obywateli oraz wykonywania funkcji urzędników czy sędziów ustanowiono dla nich wynagrodzenia ${ }^{3}$. To skłania do przyjęcia stanowiska, że nie tylko sprawa powszechności wyborów jest wyznacznikiem demokracji, lecz wytworzenie instytucji obywatelskich. O początkach demokracji możemy więc mówić już odniesieniu do starożytności.

Przejawy demokracji są zauważalne w różnorakich formach w okresie średniowiecza i czasach nowożytnych. Badacze tego zagadnienia zazwyczaj wskazują na przykłady kantonów szwajcarskich, miast włoskich, wspólnot chłopskich, uniwersyteckich czy

${ }^{3}$ W. Kaczocha, Demokracja proceduralna oraz republikańska, Poznań 2004, s. 41. 
sekt religijnych, $\mathrm{z}$ rzadka do tej listy dołącza się demokrację szlachecką w Pierwszej Rzeczypospolitej

\section{Zapomniana demokracja}

Ustrój Pierwszej Rzeczypospolitej był krytykowany od dawna, właściwie już przez ówczesną publicystykę zachodnioeuropejską. Wystarczy wymienić dzieło Gottfrieda Wilhelma Leibniza Specimen demonstrationum politicarum pro eligendo rege Polonorum (1668), Samuela Pufendorfa Historie der Vornehmsten Staaten und Reiche so jetziger zenit in Europa sich finden (1686) czy Bernarda O'Connora The history of Poland (1698). W odniesieniu do wieku XVIII uwagi krytyczne o ustroju ówczesnego państwa polskiego zawarto w dziele Rene d'Argensona Considerations sur le gouvernement de la France z 1765 roku czy wcześniejszych Lettres persanes (1721) oraz De l'esprit des lois (1748) Charlesa Luisa de Secondat, barona de Montesquieu oraz dzieło autorstwa Gabriela de Bonnot de Mably Du gouvernement et des loix de la Pologne z 1781 roku$^{5}$. Znacznie rzadziej formułowano pochwałę ustroju Pierwszej Rzeczypospolitej; aprobatę dla staropolskiej demokracji zawarto w rozważaniach De jure civitatis libri tres z 1673 roku autorstwa Ulrika Hubera czy wreszcie Jeana Jacques'a Rousseau Considerations sur le gouvernement de Pologne z 1772 roku$^{6}$.

Zupełnie inaczej wyglądała ocena ustroju dawnej Rzeczypospolitej oczami współczesnych jej publicystów szlacheckich. $Z$ reguły dostrzegali jedynie pozytywne aspekty jej funkcjonowania, posu-

${ }^{4}$ Ch. Tilly, Demokracja, s. 41-48; J. Jakubowski, Warunki wstępne demokracji, [w:] Demokracja - samorządność - prawo, red. T. Buksiński, K. Bondyra, J. Jakubowski, Pisma Filozoficzne 2007, t. CI, s. 21; M. Grabowska, Demokracja - teorie i społeczne nastawienia, Civitas. Studia z filozofii polityki 1998, nr 2, s. 47-52.

5 Z. Wójcik, Liberum veto, Kraków 1992, s. 56-62, Dzieje Narodu i Państwa Polskiego II-28; N. Davies, Boże Igrzysko. Historia Polski, t. I: Od początków do roku 1795, tłum. E. Tabakowska, Kraków 1991, s. 478-488.

6 Z. Wójcik, ibidem. 
wając się wręcz do formułowania przesadnych pochwał i gloryfikowania państwa jako trwałego osiągnięcia szlachty polskiej

Współcześnie czasy staropolskie budzą oceny dwuznaczne. Nadal w dużej mierze pokutują przekonania o przewadze anarchii i warcholstwa. Ostatnio jeden ze studentów Wydziału Prawa UJ w swojej pracy egzaminacyjnej $\mathrm{z}$ historii państwa i prawa polskiego napisał: „Wbrew ustanowionemu prawu nie można było czynić nic, a pod jego "przykrywką" wszystko. Jest to okres, w którym do absurdu doprowadzono zasadę liberum veto - prawną wolność słowa, która państwo i interes ogółu uczyniła zakładnikami jednostek. Sytuację tę odmieniła dopiero Konstytucja majowa. Mimo postulowanej nadrzędności prawa stało się ono niewolnikiem w służbie $10 \%$ szlacheckiej mniejszości, która za jego pomocą doprowadziła kraj do upadku”.

Skąd biorą się takie oceny? Jest to, jak sądzę, pokłosie trwających już dwa wieki rozważań na temat przyczyn upadku polskiej państwowości w XVIII wieku. Krakowska szkoła historyczna doszła do wniosku, że winna jest szlachta, która utraciła poczucie odpowiedzialności za państwo, które wcześniej ogromnym wysiłkiem zbudowała ${ }^{8}$. To przeświadczenie dominowało również $\mathrm{w}$ okresie międzywojnia wśród historyków i polityków ${ }^{9}$. Przyczyniła się do tego w znacznej mierze książka Władysława Konopczyńskiego Liberum veto. Studyum porównawczo-historyczne, wydana następnie w tłumaczeniu na język francuski w Paryżu w 1930 roku ${ }^{10}$. Autor nie ukrywał swojego osobistego nastawienia do posunięć szlachty staropolskiej, począwszy od połowy XVII wieku; jego poglądy nacechowane były głęboką, widoczną niechęcią, stąd język tego wybitnego skądinąd dzieła $z$ obiektywizmem, koniecznym dla rozważań

7 Szerzej H. Olszewski, Sejm Rzeczypospolitej epoki oligarchii 1652-1763. Prawo-praktyka-teoria-programy, Poznań 1966, s. 24-26.

8 M. Bobrzyński, Dzieje Polski w zarysie, Warszawa 1879, s. 447.

9 Michał Bobrzyński o potrzebie „silnego rzadu” w Polsce, oprac. P. Majewski, Warszawa 2001, s. 44-45, 52-55; także por. Stanisław Grabski o sejmie, samorzadzie i zadaniach państwa, oprac. K. Kawalec, Warszawa 2001, s. 39, 81.

${ }^{10}$ W. Konopczyński, Le liberum veto. Etude sur le developpment du principe majoritaire, Paris 1930. 
naukowych, niewiele miał wspólnego. To dzięki temu dziełu zarówno w Polsce, jak i na zachodzie Europy z czasów demokracji szlacheckiej $z$ reguły przytacza się instytucje liberum veto i elekcyjność tronu, stanowiące wówczas „źrenice wolności” szlacheckiej, oceniane jako największe nieszczęścia, które doprowadziły do upadku państwa. Stosunkowo niedawno główne tezy jego pracy zostały przytoczone $\mathrm{w}$ wydanym $\mathrm{w}$ języku angielskim zbiorowym opracowaniu o dziejach polskiego parlamentaryzmu ${ }^{11}$. Dwuznaczną opinię o staropolskim ustroju wydał również Norman Davies, tytułując jeden $z$ rozdziałów swego dzieła Boże Igrzysko, wydanego w oryginale w Nowym Jorku również w języku angielskim, pejoratywnie kojarzącym się sformułowaniem Anarchia. Demokracja szlachecka ${ }^{12}$. Autor uznał, że „anarchizm polityczny stał się jednym z przewodnich ideałów demokracji szlacheckiej”, zauważył przy tym, że w literaturze od XIX wieku Pierwsza Rzeczpospolita wystawiona była na „pośmiewisko” ${ }^{13}$. Rzeczywiście w tym czasie i później, w okresie międzywojnia za głównego winowajcę upadku Rzeczypospolitej uznawano szlachtę. Należy wszakże zauważyć, że pomimo niesprzyjających w okresie Polski Ludowej okoliczności wydawano publikacje, które opisywały ten okres w ogólnym rozrachunku w sposób pozytywny ${ }^{14}$. Dziwić może, że w wielu współczesnych publikacjach z zakresu politologii, socjologii czy filozofii polityki okres demokracji szlacheckiej pozostaje nieznany. W pracach Jaremy Jakubowskiego, Andrzeja Błaszczyka, Roberta Borkowskiego, Marii Marczewskiej-Rytko czy Pawła Śpiewaka, odwołujących się do dawnych przykładów demokratycznych, Rzeczpospolita Obojga Narodów $z$ jej demokratycznym ustrojem nie została zauwa-

11 W. Czapliński, Parliament at the Summit of Its Development (16th-17th Centurie). Antologies, Wrocław-Warszawa-Kraków-Gdańsk 1995.

12 N. Davies, God's playground. A history of Poland, v. I: The origins to 1795, New York 1982.

13 N. Davies, Boże Igrzysko, s. 427.

14 Por. K. Matwijowski, J. Pietrzak. Słowo wstępne, [w:] Senat w Polsce. Dzieje i teraźniejszość. Sesja naukowa Kraków 25 i 26 maja 1993, red. K. Matwijowski, J. Pietrzak, Warszawa 1993, s. 5-6. 
żona ${ }^{15}$. Nie jest to oczywiście regułą, inni autorzy, jak Mirosława Grabowska, Lucyna Rajca czy Beata Pająk, dostrzegli funkcjonowanie demokracji w naszej dalszej przeszłości ${ }^{16}$.

\section{Krytyka demokracji współczesnej}

We literaturze przedmiotu kondycję współczesnej demokracji poddaje się zdecydowanej krytyce. Demokracja przeradza się w formę „elitarystyczną”, rządy obywateli stają się fikcją, zastępuje je partiokracja, która dodatkowo „wyradza się”, uzyskując charakter mafijny, powstają „kliki”, niemające nic wspólnego $\mathrm{z}$ systemem demokratycznym. Społeczeństwo ma w stosunku do polityków coraz mniej zaufania. Dzieje się tak m.in. $z$ powodu uzależnienia rządzących oraz wymiaru sprawiedliwości od oligarchów; zresztą nie tylko kapitalizm przybrał postać oligarchiczną - same partie i ich przywódcy stali się oligarchami. Ogląd rzeczywistości prowadzi członków społeczeństwa do demoralizacji; zauważalny jest brak wartości etycznych, poczucia wspólnotowości, dominuje prymitywny konsumpcjonizm, co prowadzi do frustracji, niezadowolenia, poczucia niepokoju, krzywdy i głębokiej niesprawiedliwości. Narasta przekonanie, że ludzie nie są nagradzani za zasługi i cnoty, a karani za wady i przewinienia, w szczególności wtedy, gdy w grę wchodzą sprawy publiczne ${ }^{17}$. Wolność rozumie się w sposób coraz

15 J. Jakubowski, Warunki wstępne; A. Błaszczyk, Demokracja w myśleniu i działaniu. $Z$ historii demokracji - jej perspektywy, Warszawa 2004; R. Borkowski, Definiowanie demokracji, [w:] Demokracja. Teorie. Idee. Instytucje, red. T. Biernat i A. Siwik, Toruń 2003; M. Marczewska-Rytko, Demokracja bezpośrednia $w$ teorii i praktyce politycznej, Lublin 2001; P. Śpiewak, Obietnice demokracji, Warszawa 2004.

16 M. Grabowska, Demokracja; L. Rajca, Demokracja. Studium polityczne, Toruń 2007; B. Pająk, Demokracja polska i niemiecka. Tradycja, teraźniejszość, perspektywy, Poznań 2008.

17 M. Marczewska-Rytko, Demokracja bezpośrednia, s. 17; J. Miklaszewska, Demokracja - dzieje pojęcia, [w:] Oblicza demokracji, red. R. Legutko i J. Kłoczowski, Kraków 2002, s. 22-23; A. Chodubski, Wybory jako instytucja ładu demokratycznego, [w:] Czy upadek demokracji? Idee i wartości, red. A. Stelmach, Poznań 2007, s. 8-12; J. Reykowski, Wstęp, [w:] Konflikt 
bardziej pojemny, nie przewiduje się żadnych jej ograniczeń, a przede wszystkim odpowiedzialności. Brak między nimi związku powoduje, że demokracja wyrodnieje; aby więc dobrze funkcjonowała, potrzebne są przejrzyste procedury, ale także trwałe wartości, przede wszystkim zachowanie ludzkiej godności. Demokratyczną substancję niszczy brak dobrych obyczajów, arogancja wobec partnerów dyskursu politycznego, czasem wręcz jawna nienawiść. Tymczasem wypracowanie akceptowanych powszechnie zasad stało się we współczesnym świecie bardzo trudne ze względu na skrajny indywidualizm, który preferuje postawy nonkonformistyczne i wszelkiego rodzaju odmienności.

Zdaniem badaczy Europa przeżywa kryzys demokracji, w której najważniejszą rolę odgrywają wybory ${ }^{18}$. Owa „demokracja wyborcza”, w opinii Roberta Dahla, następuje wówczas, gdy głosowanie uważa się za konieczny, naturalny i podstawowy mechanizm demokracji, w efekcie następuje skupienie się na liczeniu głosów w celu ustalenia większości. W związku z tym poddawana jest krytyce sama zasada większości ${ }^{19}$. „Dlaczego myślimy - pisze Michael Saward - że głosy wyborcze tak się liczą? Głosowanie nie jest koniecznym ani naturalnym podstawowym mechanizmem demokracji. Przywykliśmy, by je za takie uważać”20.

i porozumienie. Psychologiczne podstawy demokracji deliberatywnej, red. J. Reykowskiego, Warszawa 2007, s. 9; S. Filipowicz, O władzy iluzji w królestwie rozumu, Warszawa 2007, s. 47; J. Ryfkin, Wiek dostępu. Nowa kultura hiperkapitalizmu, $w$ której płaci się za każda chwilę życia, przeł. E. Kania, Wrocław 2003, s. 205-206, 259. A. Błaszczyk, Demokracja $w$ myśleniu, s. 307; A. Szahaj, Niesprawiedliwość a demoralizacja, [w:] Demokracja spektaklu? Kondycja polskiego życia publicznego 15 lat po zmianie systemowej, red. P. Żuk, Warszawa 2004, s. 33-43.

${ }_{18}$ Ch. Tilly, Demokracja, s. 19, A. Przeworski, M. Alvarez, J.A. Cheibub, F. Limongi, Co decyduje o trwałości demokracji?, Civitas. Studia z filozofii polityki 1998, nr 2, s. 10.

19 J. Jakubowski, Warunki wstępne, s. 31-32; K. Bachmann, Konwent o przyszłości Europy. Demokracja deliberatywna jako metoda legitymizacji władzy $w$ wielopłaszczyznowym systemie politycznym, Wrocław 2004, s. 46-47; W. Palaver, Etyczne granice stosowania zasady większości - o politycznej teologii demokracji, Civitas 1998, nr 2, s. 187.

20 M. Saward, Demokracja, tłum. A. Burek, Warszawa 2008, s. 39. 


\section{Nowe koncepcje demokracji}

Model demokracji deliberatywnej wyrósł na niepokoju o przyszłość demokracji „wyborczej” i demokracji „większościowej”. Początek temu kierunkowi badań dał Jürgen Habermas, który w 1962 r. opublikował swoją rozprawę habilitacyjną Strukturwandel der Öffentlichkeit, poświęconą tytułowej przestrzeni publicznej (sferze publicznej). Autor omówił ewolucję tego pojęcia, dochodząc do wniosku, że owa sfera publiczna została obecnie zdominowana przez interesy partykularne. Dowodził, że skutkiem tego nastąpił schyłek demokracji przedstawicielskiej. Na bazie tej krytyki powstała teoria deliberatywna, oparta na założeniu, że decyzja nie musi zostać podjęta w wyniku głosowania. Legitymacja decyzji wywodzi się z możliwości partycypacji wszystkich zainteresowanych, którzy czują się „współautorami prawa” ${ }^{21}$. Nie jest wówczas ważne, czy prawo zostało uchwalone większością głosów, ani także czy jest ono sprawiedliwe. Przez uczestników deliberacji o kształcie tego prawa jest ono uważane „za swoje”. „Przestrzeń publiczna” staje się źródłem deliberacji nie zaś jej rezultatem ${ }^{22}$.

Autorem samego określenia „demokracja deliberatywna” jest James Bohman, który opublikował w „Journal of Political Philosophy" artykuł zatytułowany The comming of age of deliberative democracy. Odmianą demokracji deliberatywnej jest demokracja dyskursywna Johna Dryzeka ${ }^{23}$.

Michael Saward proponuje ograniczenie ważności aktu głosowania na rzecz powszechnej debaty $z$ udziałem obywateli bezpośrednio, nie zaś form pośredniczących: „Dlaczego - pyta - zamiast tego nie pojawia się na przykład rozmowa, albo lepiej - dyskusja. Skoro mają być podjęte kolektywne decyzje, dlaczego nie dyskutować w grupach o sprawie, aż pojawi się forma konsensusu - albo jeśli się nie uda, przynajmniej jakaś użyteczna forma "zgody na niezgodę«?"24. Dzięki udziałowi w debacie możliwe stają się przekształce-

21 K. Bachmann, Konwent, s. 50-51.

22 Ibidem, s. 54.

23 M. Saward, Demokracja, s. 145.

24 Ibidem, s. 39-40. 
nia preferencji obywateli, być może źle poinformowanych. Istotą partycypacji w świetle tych teorii jest debata publiczna oparta na ściśle określonych zasadach.

Według Habermasa do regulowanego prawem dyskursu powinni mieć dostęp wszyscy potencjalnie zainteresowani uczestnicy na zasadach równouprawnienia. Dyskusja, otwarta na możliwe tematy, powinna odbywać się bez jakiegokolwiek przymusu (zewnętrznego i wewnętrznego). Po jej ukończeniu i przyjęciu jakiegoś rozstrzygnięcia powinna istnieć możliwość późniejszej rewizji rezultatów obrad. Brak przymusu powoduje oddzielenie interesów partykularnych od interesów powszechnych. Te pierwsze, zazwyczaj sprzeczne, powodują konflikty, w trakcie których padają groźby i obietnice; można je rozstrzygać metodą kompromisów. Interesy powszechne należy poddawać analizie, opartej na przekonywaniu, perswazji i wymianie argumentów, prowadzących do konsensusu ${ }^{25}$.

Jedną $z$ form dyskursu powinna być debata w parlamencie ${ }^{26}$. Nie chodzi wszak o ograniczenie demokracji reprezentatywnej, lecz właściwe jej wykorzystanie dla potrzeb twórczej dyskusji.

Prezentowane modele opierają na szerokim zastosowaniu deliberacji, pojmowanej jako bardziej zaawansowana forma komunikacyjnych interakcji. W odróżnieniu od tradycyjnych form dyskursywnych w demokracjach reprezentacyjnych deliberację wyróżnia dążenie do osiągnięcia wspólnego efektu poczucia wspólnotowości, co wiąże się z możliwością zmiany poglądów jej uczestników. Jacek Sroka podaje za J. Habermasem pięć cech charakteryzujących udaną deliberację jako wolną od przymusu dysputę jawną i inkluzywną, dokonującą się za pomocą argumentów. Uczestnicy dyskusji dążą do osiągnięcia racjonalnie motywowanej zgody w sprawach, które powinny być uregulowane w imię dobra wspólnego ${ }^{27}$. Głosowanie większościowe jest dopuszczalne tylko w wyjątkowych oko-

25 K. Bachmann, Konwent, s. 51-53.

26 M. Saward, Demokracja, s. 147.

27 J. Sroka, Instytucje demokracji deliberacyjnej $w$ polskim systemie politycznym. Wprowadzenie do kontekstu teoretycznego, [w:] Wybrane instytucje demokracji partycypacyjnej $w$ polskim systemie politycznym, red. J. Sroka, Warszawa 2008, s. 16. 
licznościach (jeśli dobrowolnie uczestnicy się na zakończenie w taki sposób zgodzili) lub nie ma innego wyjścia ze względu na nacisk zewnętrzny, jedynym ograniczeniem jest konieczność zamknięcia deliberacji w określonym czasie konkretnym rezultatem.

W modelu Arenda Lijpharta została zaproponowana zasada weta mniejszości, zmuszająca instytucje do poszukiwania konsensusu. Jacek Sroka zwraca jednak uwagę na niebezpieczeństwo blokowania decyzji przez grupy mniejszościowe. Rozwiązanie problemu dostrzega w wypracowaniu konwencji. Na straży ich przestrzegania należałoby postawić odpowiednie gremium, niemające jednak nic wspólnego $z$ „tyranią większości”. Celem demokratycznej deliberacji jest dobro powszechne, wola powszechna oraz sprawiedliwość ${ }^{28}$.

\section{Demokracja deliberacyjna w Rzeczypospolitej Obojga Narodów}

Wybory w okresie staropolskim, aczkolwiek zajmujące znaczące miejsce w systemie ustrojowym, nie odgrywały jednak najważniejszej roli. Niewątpliwie za szczególnie istotną uznawano elekcję władcy, odbywającą się viritim; każdy szlachcic mógł przybyć na pole elekcyjne, by dokonać wyboru swego monarchy. Okres bezkrólewia, choć trudny ze względu na potrzebę ciągłego i stałego wykonywania władzy państwowej, dawał możliwość oceny panujących w państwie porządków i podjęcia debaty nad ewentualnymi zmianami. Najbardziej twórczy pod tym względem okres nastąpił po śmierci Zygmunta Augusta. Na sejmie elekcyjnym odbywającym się na polach wsi Kamień pod Warszawą uchwalono akt regulujący podstawowe zagadnienia ustrojowe, od imienia pierwszego władcy elekcyjnego - Henryka Walezego, zwany Artykułami henrykowskimi ${ }^{29}$. Należy wszakże dodać, że ów monarcha, korzystając z zamieszania wywołanego treścią artykułu drugiego, traktującego o tolerancji religijnej, ostatecznie go nie zaprzysiągł; uczynił to

28 Ibidem, s. 20-22.

29 S. Płaza, Wielkie bezkrólewia, Kraków 1988, s. 11, 20, Dzieje Narodu i Państwa Polskiego II-22. 
dopiero jego następca - Stefan Batory ${ }^{30}$. Od elekcji Władysława IV Wazy Artykuły henrykowskie połączono z paktami konwentami, regulując dodatkowo sprawy incompatibiliów, wakansów, zarządu dobrami stołowymi ${ }^{31}$. Co było w owych czasach charakterystyczne, w czasie interregnum podejmowano różne zadawnione zagadnienia, których nie udawało się uregulować w trakcie panowania poprzedniego monarchy; do nich należała głównie kodyfikacja prawa, sprawa kompozycji między stanami, egzekucji prawa, interwencji w kwestiach nadużyć prawa ${ }^{32}$. Egzorbitancje były sygnalizowane wielokrotnie ${ }^{33}$. Przed wyborem Michała Korybuta, jak wynika $z$ ich spisu, zamieszczonego w aktach sejmu walnego elekcyjnego z 1669 roku, domagano się realizacji istotnych postulatów rangi ustrojowej; elekt musi wyznawać religię rzymskokatolicką, nie może abdykować, za niedopuszczalne uznano nie tylko jakiekolwiek próby przeprowadzenia, ale nawet poruszania zagadnienia elekcji vivente rege. Na dworze mogło przebywać nie więcej niż sześciu cudzoziemców, a dokumenty publiczne wychodzące $z$ kancelarii królewskiej należało sporządzać w języku polskim lub łacińskim, natomiast prywatne aczkolwiek w języku ojczystym króla, lecz przy udziale zaprzysiężonego sekretarza - Polaka. Starano się w ten sam sposób uregulować status królowej, w szczególności surowo zabraniając jej mieszania się do najważniejszych spraw Rzeczypospolitej. Jak wynika $z$ treści zaprzysiężonych przez elekta paktów konwentów, wiele $z$ owych egzorbitancji uwzględniono ${ }^{34}$. Istotne uchwały zapadały na kończącym czas bezkrólewia sejmie koronacyjnym. W 1588 roku zagwarantowano sejmowi wyłączność w sprawach, które mocą

30 Volumina Legum (dalej: VL) t. II, wyd. J. Ohryzko, Petersburg 1859, s. $160-163$.

31 Por. przykładowo pakta konwenta Władysława IV, VL t. III, s. 362-365, także Jana II Kazimierza, VL t. IV, s. 93-95.

32 Por. przykładowo akta konfederacji warszawskich 28.01.1573, VL II, s. 124-125, także 7.03.1587, ibidem, s. 226-233, 16.07.1632, VL t. III, s. 345-352, także 31.07.1648, VL t. IV, s. 74-85.

33 Por. Diariusz sejmu konwokacyjnego i elekcyjnego w 1648 r., [w:] Księga pamiętnicza Jakuba Michałowskiego, wyd. A.Z. Helcel, Kraków 1864, s. 141-142, 227-229, 298.

34 VL t. V, s. 13-18. 
prawa zwyczajowego lub stanowionego trafiały pod jego obrady. Inna $z$ konstytucji wówczas uchwalonych dotyczyła podstawowych elementów procesu legislacyjnego: przygotowania uchwały sejmowej w trakcie obrad sejmu, ,zgodnego” przyjęcia projektu oraz podpisania przez reprezentantów senatu i izby poselskiej, odczytania tekstu w obecności króla oraz, po aprobacie wszystkich uczestników, złożenia pieczęci przez kanclerza lub podkanclerzego ${ }^{35}$. $Z$ kolei na sejmie koronacyjnym Władysława IV postanowiono w tej mierze, że przedmiotem konkluzji sejmowej mają być tylko projekty wczesniej zgodnie przyjęte w izbie poselskiej. Przeciwdziałając zjawisku prolongaty obrad sejmowych, która „przeciwko prawu y zwyczaiowi przychodzi”, zobowiązano posłów do łączenia się z senatem na pięć dni przed terminem konkluzji na sejmach sześciotygodniowych ${ }^{36}$. Modus eligendi regis uszczegółowiono, zakazując kandydatom przebywania na polu elekcyjnym dla zapobieżenia groźbie korupcji ${ }^{37}$.

Szlachta dokonywała wyboru nie tylko króla; na zwoływane przez niego sejmy wybierała posłów, do Trybunału Koronnego i Litewskiego delegowała deputatów, ponadto proponowała po czterech kandydatów na wakujący urząd sędziego, podsędka lub pisarza, wybierała również komisarzy do korektury prawa, rewizji zniszczonych ksiąg ziemskich, spraw menniczych, a w późniejszych czasach także rotmistrzów wojsk powiatowych. Wybór przedstawicieli szlachty jako metoda wyłaniania składu osobowego różnego rodzaju władz był wówczas szeroko stosowany. W tych celach zwoływano często sejmiki powiatowe oraz generalne, w których miał prawo uczestniczyć każdy szlachcic. Były to organy demokracji bezpośredniej o znaczeniu nie do przecenienia, skoro w schyłkowej formie demokracji szlacheckiej mamy do czynienia wręcz z „rządami sejmikowymi".

Choć ówcześnie obywatele szlacheccy uczestniczyli w wyborach w szerszym zakresie niż to jest obecnie, nie odgrywały one tak istotnej funkcji jak współcześnie. System staropolski służył szero-

35 1588, pkt 4, O konstytucyach Seymowych, VL t. II, s. 252.

36 1633, pkt 9, Konkluzya Sejmowa, VL t. III, s. 373.

37 1633, pkt 4, Candidatus Regni, Conventui Electionis non intersit, VL t. III, s. 372 . 
kiej partycypacji obywateli, nawet w sytuacjach, gdy przewidywano zastosowanie zasad reprezentacji. Narzędziem do tego celu był rodzaj mandatu, który nazywamy dziś związanym, czyli imperatywnym. Posłowie „od braci” mieli poruczone przedstawienie na sejmie stanowiska swoich wyborców dotyczącego materii poruszonych w instrukcji królewskiej, a nadto spraw zarówno o charakterze ogólnopaństwowym, jak i lokalnym, o załatwienie których sejmik zabiegał na sejmie. Treść pełnomocnictwa była zawarta w instrukcji poselskiej, będącej jednocześnie potwierdzeniem wyboru. Brak instrukcji oznaczał brak mandatu. Jednak na sejmie w 1596 roku posłowie ruscy, wybrani przez część szlachty na rozdwojonym sejmiku, poddani rugom na początku obrad, bronili się twierdzeniem, że jeśli uzyskali pełnomocnictwo nieograniczone, to instrukcja jest im niepotrzebna. Ich argumentacja nie przekonała jednak obecnych, choć zgodzili się na pozostawienie posłów w izbie ${ }^{38}$. Podobnie zdarzyło się w Upicie w 1631 roku, gdy z powodu szerzącej się zarazy sejmik wystawił dla posłów jedynie „membran wierzący”, czyli poświadczenie wyboru; sądzić należy, że posłowie pojechali na sejm bez instrukcji ${ }^{39}$. Jednak taką sytuację traktowano jako wyjątek, odstępstwo od obowiązujących reguł z powodu vis maior. Konieczność wystawienia instrukcji wydaje się przesądzona.

W pierwszej części instrukcji sejmik jako organ demokracji bezpośredniej, po pozdrowieniu monarchy i życzeniach zdrowia oraz pomyślności oraz zapewnieniach o wierności, ustosunkowywał się do instrukcji królewskiej do niego skierowanej ${ }^{40}$.

38 Biblioteka Jagiellońska rkps 6251 IV, k. 80 v.

39 Por. J. Seredyka, Rzeczpospolita $w$ ostatnich latach panowania Zygmunta III (1629-1632). Zarys wewnętrznych dziejów politycznych, Opole 1978 , s. 89.

40 „My, którzyśmy się tu na sejmik proszowski według listów sejmikowych (sejmowych), od króla JM wydanych, wedla prawa starego zgromadzili, wysłuchawszy instrukcyej Króla JM. i obmowy albo dania sprawy od J.K.M., pana naszego miłościwego", Instrukcja sejmiku przedsejmowego województwa krakowskiego, Proszowice 12.08.1592, Akta sejmikowe województwa krakowskiego, t. I: 1572-1620, wyd. S. Kutrzeba, Kraków 1932 (dalej: Kutrzeba), s. 181, także por. „Wziąwszy tedy propozycyą przed się 
Z treści instrukcji poselskiej wprost wynikało, jakie zamiary kierowały sejmikiem; czy udzielał pełnomocnictwa nieograniczonego, czy było ono ograniczone. Ten drugi rodzaj zdecydowanie przeważał. Limitata potestas nazywano „mocą zamierzoną” ${ }^{41}$. W im większym konflikcie znajdowały się najważniejsze siły polityczne (dwór i naród szlachecki) tym więcej pojawiało się ścisłych zaleceń. Zdarzało się, że postępowanie posłów na sejmie starano się dokładnie zaplanować. W instrukcji na sejm 1592 roku, gdy posądzano króla o zdradę Rzeczypospolitej, sejmik w Proszowicach domagał się rozpoczęcia obrad od "statecznej inquisitionis uczynionej około praktyk cudzoziemskich z strony Korony tej”, która trwać powinna przez pierwsze dwa tygodnie obrad sejmu. Sejmik bezwzględnie zakazał podejmowania przez posłów jakichkolwiek decyzji w tej sprawie bez porozumienia się z „braciej województwa tego”, która była gotowa stawić się w każdym miejscu i czasie w razie takiej potrzeby. Zakładano wszakże, że jeśli tego planu nie uda się zrealizować, posłowie mają „w dalsze sejmowe sprawy nie wdawając się, społu $z$ drugą bracią o sobie i bezpiecznym ojczyźnie radzić i tym niebezpieczeństwom zabiegać" 42 . W ten sposób posłom dano wolną rękę co do dalszych działań, ograniczając ich tylko zaleceniem wspólnych konsultacji $z$ innymi województwami.

Instrukcja sejmikowa stawała się aktem niemalże szantażu, gdy monarcha znajdował się w trudnej sytuacji, wymagającej pomocy szlachty. Tak szlachta krakowska potraktowała wezwania Zygmunta III o udzielenie pomocy finansowej na „rekuperacyę Swecyej” przed sejmem w 1600 roku. Posłom nakazano najpierw przedstawić postulaty województwa zawarte w instrukcji i tylko w wypadku ich uwzględnienia zezwolono na uchwalenie środków finansowych na poratowanie króla, i to tylko wówczas, gdy też „insze województwa

J.K.K. [J.K.M. - ILM] i uważając dostatecznie wszystkie punkta jej”, Instrukcja sejmiku województwa krakowskiego, Proszowice 27.01.1597, ibidem, s. 209.

${ }^{41}$ Instrukcja z sejmiku przedsejmowego województwa krakowskiego, Proszowice 10.11.1584, Kutrzeba, s. 100.

42 Instrukcja sejmiku przedsejmowego województwa krakowskiego, Proszowice 12.08.1592, Kutrzeba, s. 184-183. 
J.K.M. jaki rachunek podadzą"43. Absolutam potestatem daną posłom w sprawach jednoznacznych zaznaczano w instrukcji bardzo wyraźnie. Gdy przedmiotem obrad sejmu 1597 roku miała być sprawa przyłączenia się do ligi antytureckiej, sejmik proszowski udzielił nieograniczonego pełnomocnictwa ad hunc solum actum ${ }^{44}$. Postanowienia instrukcji wiązały posłów w największym stopniu w części stanowiącej odpowiedź na instrukcję królewską, a głównie w sprawach podatkowych. Należy wszakże zauważyć, że instrukcja królewska miała częstokroć charakter ogólnikowy; zawierała opis stanu państwa, prowadzonej w okresie przedsejmowym polityki zagranicznej, była zatem ogólnym projektem programu obrad. Ogólnikowe sformułowania dawały szerokie możliwości interpretacji, często niektóre kwestie zupełnie pomijano. Prośby króla o udzielenie wsparcia finansowego rozpatrywano bardzo wnikliwie; chodziło wszak o dobrowolne, nadzwyczajne podatki. W tym względzie udzielane pełnomocnictwa miały najczęściej charakter bezwzględnie wiążący ${ }^{45}$. Jeśli sejm uchwalił wyższe pobory, nadwyżkę ponad wielkość ustaloną w instrukcji sejmikowej poseł „brał do braci na sejmik" 46 .

Plena potestas była wyjątkiem od stosowanej reguły ograniczania posłów w ich działaniach czynionych na sejmie, choćby w formie

43 Instrukcja przedsejmowa sejmiku województwa krakowskiego, Proszowice 3.02.1600, Kutrzeba, s. 233-234.

44 Instrukcja, Proszowice 27.01.1597, Kutrzeba, s. 210.

45 „A my z ochoty naszy i uprzejmy chęci przeciwko J.K.M., p.n.m., królewicowi JM. in subsydium dwa pobory jeden po drugiem przez dwu lat po sobie idących, tj. in Anno 1616 i in Anno 1617, wedle uniwersału anni 1587 i kwitów ostatecznych pozwalamy", instrukcja, Środa 8.03.1616, Akta sejmikowe województw poznańskiego i kaliskiego, kaliskiego, t. I (1572-1632), cz. 1 (1572-1616), wyd. W. Dworaczek (dalej: Dworzaczek I), Poznań 1957, s. 489.

46 W 1620 sejmik średzki zgodził się na dwa pobory z czopowym, por. Akta sejmikowe województw poznańskiego i kaliskiego, kaliskiego, t. I (1572-1632), cz. 2 (1617-1632), wyd. W. Dworzaczek (dalej: Dworzaczek II), Poznań 1962, s. 88, w uniwersale poborowym król, w związku z wojną, wyraził nadzieję, że pozostałe sześć sejmik pozwoli wydać, VL t. III, s. 187, 196. 
luźnych zaleceñ ${ }^{47}$. Sformułowania instrukcji poselskich są w tym względzie niezwykle różnorodne, wśród których przeważają następujące: „pp. posłowie (z wielką pilnością) starać się mają, upominać się mają pp. posłowie" ${ }^{48}$. W tym kontekście instrukcja była rodzajem przewodnika, podpowiedzią dla posłów, jakie problemy powinni poruszyć; liczono się jednak $z$ brakiem możliwości załatwienia sprawy na sejmie. W jeszcze mniejszym zakresie instrukcja wiązała posłów w sprawach petytów, będących przedmiotem interwencji poselskich w sprawach indywidualnych. Ich rolą było przedstawienie „prośby”, jednak nikt nie mógł żądać od posła, by ten osiągnął cel, określony w owym petitum. Moc wiążąca instrukcji polegała głównie na obowiązku przedstawienia sprawy na sejmie, rzadko wymagano jej załatwienia w sposób identyczny z wytycznymi. W większości przypadków można więc mówić o instrukcji w znaczeniu formalnym, a nie materialnym. Należy sądzić, że skuteczność czyniła posła bardziej wiarygodnym, jego pozycja była silniejsza, miał więc szansę nie tylko na zyskanie sobie szacunku wśród braci, ale ponowny wybór na posła lub inną funkcję publiczną.

Szczególną rolę w Rzeczypospolitej odgrywała debata publiczna. Odbywała się przede wszystkim na sejmikach i innych zjazdach szlacheckich, zwoływanych $z$ różnorodnych okazji. Wszędzie debatowano nad sprawami państwa. Na ogół szlachta była dobrze w nich zorientowana, przygotowana merytorycznie do prowadzenia dysputy. Nawet w czasach saskich, jak zauważył Janusz Ekes, „ponury idiotyzm" języka ówczesnych debat był wynikiem zapotrzebowania, a nie rzeczywistego braku kompetencji ówczesnych statystów życia publicznego ${ }^{49}$. Osią obrad sejmowych była nieskrępowana debata nad sprawami będącymi przedmiotem obrad, w czasie których marszałek wykonywał funkcję moderatora udzielającego głosu,

47 Por. „ich. pp. posłowie [...] mają się znosić z inszymi pany posły, przychylając się do tego, co by było $z$ najlepszym R.P. W którym tylko samym artykule zupełną moc imchmciom pp. posłom naszym dajemy”, instrukcja, Środa 29.01.1613, Dworzaczek I, s. 415.

48 Przykładowo instrukcja, Środa 25.03.1593, Dworaczek I, s. 164.

49 J. Ekes, Polska - przyczyna słabości i podstawy nadziei, Warszawa 1994, s. 20. 
łagodzącego nastroje i pilnującego, by dyskurs był w miarę monotematyczny.

Deliberacja publiczna dotyczyła wspólnego dobra, jakim była Rzeczpospolita. I choć pojęcie to nie było wyraźnie skonkretyzowane, starano się go odróżnić od „prywaty”. Sam fakt ich rozróżnienia jest wiele znaczący. W zachowaniach i treściach przemówień uczestników dyskursu poszukiwano właściwych intencji. Dlatego obdarzano zaufaniem osoby samodzielne w myśleniu i działaniu, nieskażone podejrzeniem o „trzymanie się pańskiej klamki”. „Rękodajnych" nie chciano wybierać na posłów; uważano, że nie będą właściwie reprezentować swoich wyborców, lecz forsować interesy swoich mocodawców ${ }^{50}$. Dopiero w schyłkowym okresie demokracji szlacheckiej zapanowała „dyscyplina partyjnej lojalności” względem fakcji magnackich ${ }^{51}$.

Dzięki mechanizmowi zależności posłów od sejmików przedstawiciele powinni reprezentować interesy swoich wyborców. Szlachta miała znaczący wpływ na treść uchwalanego w Rzeczypospolitej prawa. $Z$ jednej strony proces legislacyjny w całości, włącznie z przygotowaniem projektu konstytucji, powinien zostać przeprowadzony na sejmie, $z$ drugiej zaś kierowanie posunięciami posłów przez wysyłające ich sejmiki oraz możliwość wniesienia protestacji, które można porównać do dzisiejszej instytucji weta, dawały przewagę formułom demokracji bezpośredniej. Starano się pogodzić potrzebę szerokiej partycypacji obywatelskiej z zasadami reprezentacji, uwzględniając ponadto rozdział kompetencji sejmików i sejmu.

Krytykowane stanowisko szlachty, niechętnej stosowaniu zasady większości, w świetle idei demokracji deliberatywnej, staje się bardziej zrozumiałe. Starano się wówczas osiągnąc stan zgody, dzięki której mniejszość nie jest zmuszana do uznania zdania większości ${ }^{52}$. Unikano eskalacji konfliktów, dążąc do stanu harmonii i równowagi, początkowo przede wszystkimi między trzema „stanami

50 Por. J. Dzięgielewski, Stan szlachecki $w$ życiu publicznym Rzeczypospolitej $w$ pierwszym stuleciu po unii lubelskiej, [w:] Tradycje polityczne dawnej Polski, red. A. Sucheni-Grabowska i A. Dąbrowska, Warszawa 1994, s. 106.

51 J. Ekes, Polska - przyczyna słabości, s. 47.

52 J. Reykowski, Wstęp, s. 9. 
sejmującymi”, będącymi emanacją Rzeczypospolitej, a później także w obrębie izby poselskiej. W cenie była umiejętność szermowania przekonującymi argumentami w atmosferze szacunku do pozostałych uczestników dyskursu. Wierzono, że jest możliwe przekonanie oponenta. Poczucie szacunku, tolerancji i zrozumienia miało górować nad chęcią przeforsowania swojego stanowiska za wszelką cenę. W dobie „złotej demokracji” uważnie słuchano zdania dyskutantów, rozważano je niezależnie od statusu majątkowego czy zajmowanego przez rozmówcę stanowiska lub urzędu. Pełnienie funkcji poselskiej dawało możliwość rozwoju kariery nawet najskromniejszemu szlachcicowi. Bardzo dobrym przykładem jest droga życiowa Jana Zamoyskiego, któremu ojciec w spadku zostawił cztery wsie; należał więc do średniej szlachty ${ }^{53}$.

Prawo przyjęte bez wyraźnego sprzeciwu traktowano jako owoc wspólnego wysiłku; dobrowolna akceptacja za zgodą wszystkich sprzyjała jego egzekucji. Postanowienia, do których przekonano uczestników, uznawano za wartościowe i choć obarczone wieloma brakami w zakresie techniki legislacyjnej, były dla ówczesnych adresatów zrozumiałe. Jeśli ich treść wzbudziła jakieś wątpliwości, poprawiano je ponownie na sejmie. Sprawy budzące wątpliwości sprzeciw, wewnętrzny konflikt porzucano lub zajmowano się nimi ponownie w późniejszym czasie. Za wartość najwyższą uznawano osiągnięcie wzajemnego porozumienia w imię „braterskiej miłości”. Znaczącą rolę odgrywały zasady religii chrześcijańskiej, którymi kierowano się w działaniach publicznych. Na solidarność w izbie poselskiej wpływ miał niewątpliwie toczący się spór inter maiestatem ac libertatem. Szlachta uznawała Rzeczpospolitą za swoje trwałe osiągnięcie, rzecz wspólną, którą ukształtowano w wyniku długotrwałych starań, wyrzeczeń i walki o wolność i prawa. Należało ją zatem pielęgnować i chronić przed wszelkimi niebezpieczeństwami zewnętrznymi i wewnętrznymi. Ta ideologia kwitła w Rzeczypospolitej przez dziesiątki lat, przynosząc trwałe owoce w postaci potęgi

53 W. Czapliński, Sejm w latach 1587-1696, [w:] Historia sejmu polskiego, t. I: Do schyłku szlacheckiej Rzeczypospolitej, red. J. Michalski, Warszawa 1984, s. 243. 
ówczesnego państwa, propagującego pokój, wewnętrzną harmonię i zgodę. Rządy prawa zapewniały reakcję na popełniane nadużycia.

Dekompozycja w łonie szlachty, odzwierciedlona w izbie poselskiej, wywołana rozbieżnymi interesami w dobie wojen ${ }^{54}$ prowokowanych przez królów elekcyjnych, a nadto ich działania zmierzające do wzmocnienia władzy w kierunku absolutum dominium, których efektem było zachwianie i zanik zaufania szlachty do swych monarchów, stały się przyczyną późniejszego upadku ${ }^{55}$. Szlachta, sądząc, że zbudowała państwo doskonałe, nie chciała zgodzić się na żadne ustępstwa w kwestii zmian ustrojowych. W obawie przed posunięciami nieuzgodnionymi $z$ wyborcami nie ufano już nawet swoim reprezentantom; posłowie nie kierowali się wskazaniami instrukcji, które coraz częściej powtarzały zalecenia wcześniejsze ${ }^{56}$. To nie szlachta popierała rozrywanie czy zrywanie sejmów; wręcz przeciwnie - w instrukcjach sejmikowych stale wskazywano na potrzebę skutecznego obradowania, zobowiązywano posłów do poszukiwania zgody $^{57}$. A gdyby postulatom zawartym w instrukcji danego sejmiku sprzeciwiły się inne województwa to zawsze ratunkiem przed upad-

54 Konflikt między prowincjami i ziemiami miał charakter fiskalny, był związany z nierównym wydawaniem poborów i konieczności koekwacji, por. „ich. pp. posłowie nasi domówią się tego [...], żeby się inne województwa, które pozostały w tym dawaniu podatków, in eo passu porównali”, instrukcja Środa, 11.12.1618, Dworzaczek II, s. 70.

55 „O wewnętrznych majestatu z wolnością kolizjach oraz dyfidencyjach między stanami” jako przyczynach upadku państwa pisał S. Dunin-Karwicki, Dzieła polityczne z początku XVIII wieku, oprac. A. Przyboś i K. Przyboś, Wrocław-Kraków 1992, s. 24.

56 Por. Instrukcja Proszowice 11.06.1652, Akta sejmikowe województwa krakowskiego, t. II: 1621-1660, wyd. A. Przyboś (dalej: Przyboś), WrocławKraków 1995, s. 437-438; Instrukcja Proszowice 19.05.1954, ibidem, s. 507, 509 .

57 Por. „aby się na to lekarstwo zaraz obmyśliło, żeby ten sejm rozerwany nie był”, instrukcja, Proszowice, 16.02.1606, Kutrzeba, s. 275; starać się mają PP. posłowie i drugich panów kolegów k temu wieść, aby nie bawiąc się szerokimi mowami do rzeczy zaraz przystępowali a nie zwłóczyli spraw R.P. na ostatni termin sejmu, co przyczyną bywa i do nieporządnego odprawowania rzeczy i czasem do niezamknięcia sejmu”, instrukcja, Proszowice, 13.12.1608, Kutrzeba, s. 332; „Przeszłych sejmów z wielką szkodą Ojczyzny rozerwanych wspomniawszy faciem, potrzebno być rozumiemy, aby 
kiem sejmu mogło być „włożenie sprawy w reces”58. Rzeczpospolita weszła w fazę ostrych walk fakcyjnych między dworami magnackimi. Zakulisowe, całkowicie nieprzejrzyste, niejawne działania monarchów, nasilone od czasów Jana Kazimierza, pogarszały jedynie wewnętrzny klimat społeczny. Konflikty zbrojne, brak pokoju, pogarszająca się stale sytuacja gospodarcza niszczyły staropolską demokrację. Szlachta, wobec zaprzestania działalności przez sejm, odwołała się do demokracji bezpośredniej, czyli rządów sejmikowych. Konflikty o władzę, przemiany ustrojowe trwały do końca istnienia Pierwszej Rzeczypospolitej ${ }^{59}$. Wewnętrznie skłócone państwo, bez śladu wewnętrznej harmonii i zgody, na których było wcześniej zbudowane, stało się łatwym łupem swych sąsiadów.

\section{Wnioski końcowe}

Jak wyraził się Zygmunt Żuławski, polski socjalista okresu międzywojnia, „demokracja jest tylko jedna: albo istnieje, albo jej nie ma” ${ }^{60}$. Można więc rzec, że w 2. połowie XVI wieku wraz z powstaniem Rzeczypospolitej Obojga Narodów doszło do rozwoju demokracji szlacheckiej w obrębie państwa o ustroju określanym jako monarchia mixta. Element monarchiczny reprezentował władca elekcyjny, senatorowie stanowili arystokrację, szlachta zaś - element demokratyczny. Formą preferowaną była demokracja bezpośrednia $z$ koniecznymi ustępstwami na rzecz stosowania zasady reprezentacji. Państwo naówczas było terytorialnie niezwykle rozległe;

z województwa wybrani ichmposłowie przysięgę wykonali na tym sejmie przed zaczęciem konsultacyi sejmowych i na potym zawsze przysięgli bywali”, instrukcja, Proszowice 28.04.1655, Przyboś, s. 537.

58 „A gdzieżby za kontradykcyjami inszych województw którykolwiek artykuł wyży pomieniony na tym sejmie stanąc nie mógł, tedy do inszego sejmu w reces to włożyć [...], aby temu wszystkiemu na drugim sejmie, da Pan Bóg, dosyć się stało”, instrukcja, Środa, 8.03.1616, Dworaczek I, s. 489 .

59 Por. R. Łaszewski, Sejm polski $w$ latach 1764-1793, Warszawa-Poznań 1973.

60 Zygmunt Żuławski o ustroju społecznym i demokracji, oprac. M. Śliwa, Warszawa 2000, s 216. 
współcześnie uważano by za rzecz konieczną wprowadzenie demokracji pośredniej. W owym czasie szlachta chciała mieć bezpośredni, osobisty wpływ na bieg spraw publicznych. Każdy szlachcic poczytywał sobie za osiągnięcie współuczestnictwo w budowie i rozwoju Rzeczypospolitej, będącej wspólnym dobrem jej obywateli. Znaczącą rolę odgrywały sejmiki będące formami demokracji bezpośredniej; do sejmikowego koła mógł zjechać każdy szlachcic. Sejmiki przez system delegowania na sejmy swoich przedstawicieli zaopatrzonych w instrukcję oraz możliwość oprotestowania uchwał sejmowych miały wpływ na kształt prawa oraz jego moc wiążącą. Dzięki temu modelowi udział obywateli w narodu szlacheckiego w kształtowanie ówczesnego prawa był nieporównanie większy niż obecnie. Było to przejawem jego wolności ${ }^{61}$.

Dobro publiczne, jakim była Rzeczpospolita, odróżniano od prywaty. Debata nad sprawami państwa rządziła się innymi zasadami niż spory sąsiedzkie czy negocjacje handlowe. Gdy w tych ostatnich kwestiach był możliwy kompromis, w sferze publicznej stosowano zasadę zgody (konsensusu), osiąganej w wyniku deliberacji równych jej uczestników. Wierzono, że oponenta da się przekonać za pomocą racjonalnych argumentów; adwersarz jest w stanie zmienić zdanie pod wpływem właściwej argumentacji. Dlatego należało cierpliwie przekonywać do swoich racji, kierując się dobrem ojczyzny, z szacunkiem traktując innych uczestników deliberacji. Zasadę większości oceniano podejrzliwie, obawiając się korupcji, ale przede wszystkim wierząc, że tylko powszechna zgoda, wyrażona przez brak sprzeciwu, zapewni pokój wewnętrzny. We współczesnym świecie, pełnym konfliktów, wzajemnej niechęci, a nawet nienawiści, szerzonej także w życiu publicznym, byłoby to niezwykle cenne osiągnięcie. Zasada zgody powszechnej w kontekście współczesnych nam rozważań nad zasadami demokracji deliberatywnej powinna zostać przewartościowana.

61 Podobnie wypowiedział się w okresie międzywojnia działacz ludowy Stanisław Thugutt: „Obywatel nie mający wpływu na kształtowanie się prawa nie jest wolny. Nie jest demokracją ustrój, którego wolność nie jest podstawą. Stanisław Thugutt o demokracji i ustroju Polski”, oprac. W. Wic, Warszawa 1998, s. 172. 
Partycypacja obywatelska przybierała znacznie obszerniejsze rozmiary niż obecnie. Szlachta, uważając się za twórcę Rzeczypospolitej, poczuwała się do jej obrony, przeznaczając na ten cel nadzwyczajne podatki, a także broniąc jej „własną piersią” w pospolitym ruszeniu ${ }^{62}$. Uczestniczyła w wymiarze sprawiedliwości, wybierając swoich kandydatów na urzędy sądowe czy wreszcie mając znaczący, jeśli nie przeważający, udział w prawodawstwie.

Staropolska demokracja powinna być przedmiotem szerszego zainteresowania nauki, i to nie tylko historycznoprawnej, skoro współcześnie propaguje się model demokracji, w której szczególną rolę odgrywają nie wybory i stosowanie zasady większości, lecz deliberacja równych sobie obywateli, a rozstrzygnięcia zapadają w wyniku powszechnej zgody. Takimi cechami charakteryzował się demokratyczny ustrój Rzeczypospolitej Obojga Narodów.

\section{SUMMARY}

\section{„Forgotten democracy”. Deliberative democracy in Poland in XVI-XVIII centuries}

In connection of crisis of democracy in modern Europe, there are new concepts of her reconstruction, including a new idea of deliberative democracy, which clearly separates public sphere from private sphere of people's life. In both of them there are different rules. In public sphere free and equal citizens care about the common good through the debate of public issues, which is conducted on the basis of freedom of speech. That deliberation, in which only substantive arguments should be used to persuade interlocutors, who express different point of view, always ends not with a vote, but with universal agreement. That idea is considered to be

62 „Nie chcąc i dalszym sposobom ratowaniu ojczyzny deese, i owszem, lubo to wielkimi i częstymi podatkami sumus exhausti, zdrowie jednak i własne piersi swe na wsparcie ojczyzny oferujemy i pospolite ruszenie, gdzie tego będzie potrzeba, przeciwko temu tylko pogaństwu pozwalamy, jeźlisz na to zgoda wszytkich stanów na sejmie zajdzie", instrukcja, Środa 27.07.1621, Dworzaczek II, s. 104. 
the future of democracy. However it should be noted that Poland has in deliberative democracy extremely interesting traditions. On deliberative democracy was based Polish democracy in XVI-XVIII centuries.

Key-words: democracy, public sphere, common good, deliberation, universal agreement 